\title{
EFEK JUS DAUN MATEL (CLERODENDRUM MINAHASSAE L.) DAN DAUN BAYAM DURI (AMARANTHUS SPINOSUS L.) DALAM MENINGKATKAN KADAR HEMOGLOBIN DAN JUMLAH ERITROSIT PADA MENCIT (MUS MUSCULUS)
}

\author{
Malawat $\mathbf{R}^{1}$, Leiwakabessy $\mathbf{F}^{1}$, Watuguly $\mathbf{T h}^{\mathbf{1}^{*}}$ \\ ${ }^{1}$ Program Studi Pendidikan Biologi, Universitas Pattimura \\ *Corresponding author: Watuguly Th \\ rivaldo.malawat@gmail.com
}

\begin{abstract}
Anemia is the second world most deadliest and crappiest cause and therefore it is one of global serious health issue (WHO, 2014). Matel (Clerodendrum minahassae L.) empirically a plant that has been utilized in Indonesia, especially in Maluku as vegetable and medicine. According to (Utami et. al., 2017) the mineral content in simplisia around $27.783 \%$. While the spiny amaranth (Amaranthus spinosus L.) contain at least $32 \mathrm{mg}$ of ferrum/100 gram. Both plant potentially could be utilized as alternative medicine to cure anemia. The purpose of this research is to know the influence of matel (Clerodendrum minahassae L.) leaf juice and spiny amaranth (Amaranthus spinosus L.) leaf juice towards the hemoglobin level and red blood cell count on mice (Mus musculus). The hemoglobin level test shows that the Treatment 1 group using Matel juice giving a great and significant effect $(p \leq 0.05)$ towards the hemoglobin level with highest mean hemoglobin level on $14,5 \mathrm{~g} / \mathrm{dL}$ and $\mathrm{RBC}$ around $7.43 \times 10^{12} / \mathrm{L}$, followed by Treatment 3 using combination juice with mean hemoglobin around 14,4 g/dL and RBC around $6.94 \times 10^{12} / \mathrm{L}$, and the lowest is on the Treatment 2 using Spiny amaranth with mean hemoglobin level around $10,5 \mathrm{~g} / \mathrm{dL}$ and $\mathrm{RBC}$ around $3.61 \times 10^{12} / \mathrm{L}$. Therefore, we could conclude that matel leaf juice and spiny amaranth juice could give a great effect on increasing hemoglobin level and RBC.
\end{abstract}

Key Words: Anemia, Hemoglobin, Erythrocyte, Matel, Spiny Amaranth

\begin{abstract}
ABSTRAK. Anemia adalah penyebab kedua terkemuka didunia dari kecacatan dan dengan demikian salah satu masalah kesehatan masyarakat paling serius global (WHO, 2014). Tanaman Matel (Clerodendrum minahassae L.) secara empiris merupakan salah satu tanaman yang banyak dimanfaatkan di Indonesia, khususnya di Maluku sebagai sayuran dan obat". Menurut (Utami et. al., 2017) Kadar abu total dalam simplisia sebesar 27,783 \%, sementara itu, Amaranthus spinosus L. mengandung setidaknya $32 \mathrm{mg}$ besi/ 100 gram. Kedua bahan berpotensi menjadi bahan alternatif dalam mengobati anemia. Tujuan penelitian ini adalah untuk mengetahui pengaruh penggunaan jus daun matel dan jus daun bayam duri terhadap kadar hemoglobin dan jumlah eritrosit pada mencit. Hasil pengukuran kadar hemoglobin menunjukkan bahwa kelompok perlakuan 1 Jus Daun Matel memberikan pengaruh yang cukup signifikan $(p \geq 0.05)$ terhadap kadar hemoglobin rata-rata tertinggi sebesar $14,5 \mathrm{~g} / \mathrm{dL}$ dan jumlah eritrosit rata-rata sebesar $7.43 \times 10^{12} / \mathrm{L}$, diikuti oleh Kelompok perlakuan 3 Jus Daun Kombinasi (Jus Daun Matel + Jus Daun Bayam Duri) dengan kadar hemoglobin rata-rata sebesar 14,4 g/dL dan jumlah eritrosit rata-rata $6.94 \times 10^{12} / \mathrm{L}$, dan yang terendah adalah pada perlakuan 2 Jus Daun Bayam Duri, dengan kadar hemoglobin rata-rata 10,5 g/dL dan jumlah eritrosit rata-rata $3.61 \times 10^{12} / \mathrm{L}$. Dengan demikian dapat disimpulkan bahwa jus daun matel dan daun bayam duri memberkan efek yang nyata dalam meningkatkan kadar hemoglobin dan jumlah eritrosit.
\end{abstract}

Kata Kunci: Anemia, Hemoglobin, Eritrosit, Matel, Bayam Duri

\section{Pendahuluan}

Anemia adalah suatu keadaan dimana kadar hemoglobin $(\mathrm{Hb})$ dalam darah kurang dari normal. Faktor-faktor penyebab anemia gizi besi adalah status gizi yang dipengaruhi oleh pola makanan, sosial ekonomi keluarga, lingkungan dan status kesehatan. Anemia adalah penyebab kedua terkemuka didunia dari kecacatan dan dengan demikian salah satu masalah kesehatan masyarakat paling serius global (WHO, 2014).

Kekurangan gizi masih dialami oleh sebagian masyarakat di Indonesia. Misalnya, kekurangan zat besi (Fe) yang dapat menyebabkan kadar hemoglobin berkurang. Menurut Hoffbrand et al. (2005), anemia didefinisikan sebagai keadaan kuantitas dan kualitas darah tidak normal yang ditunjukkan oleh ukuran atau jumlah sel darah merah dan kadar hemoglobin dalam darah berkurang. Menurut Junquera (1997) dalam dalam Munawaroh (2009) Hemoglobin $(\mathrm{Hb})$ merupakan salah satu komponen penyusun darah dan merupakan suatu derivat porfirin yang 
mengandung besi serta berfungsi dalam hal pengikatan dan pengangkutan $\mathrm{O} 2$. Hb berfungsi membawa $\mathrm{CO} 2$ dari jaringan tubuh, dengan aktivitas ini, maka $\mathrm{Hb}$ juga membantu terciptanya keseimbangan asam basa dalam darah.

Anemia karena kekurangan zat besi dipengaruhi juga oleh vitamin $\mathrm{C}$. Vitamin $\mathrm{C}$ berfungsi mereduksi besi ferri $\left(\mathrm{Fe}^{3+}\right)$ menjadi ferro $\left(\mathrm{Fe}^{2+}\right)$ dalam usus halus sehingga mudah diabsorpsi. Vitamin $\mathrm{C}$ juga menghambat pembentukan hemosiderin yang sulit dimobilisasi untuk membebaskan zat besi bila diperlukan oleh tubuh. Absorpsi zat besi dalam bentuk non hem meningkat empat kali lipat bila ada vitamin C. Vitamin C berperan dalam memindahkan zat besi dari transferin di dalam plasma ke feritin hati. Sebagian besar transferin darah membawa zat besi ke sumsum tulang dan bagian tubuh lainnya. Di dalam sumsum tulang zat besi digunakan untuk membentuk hemoglobin (Almatsier, 2001). Menurut Hoffbrand et al. (2005), sumsum tulang memerlukan prekursor seperti zat besi, vitamin C, vitamin B12, kobalt dan hormon untuk pembentukan sel darah merah dan hemoglobin.

Zat besi ( $\mathrm{Fe}$ ) dan vitamin $\mathrm{C}$ merupakan faktor yang berhubungan dengan pembentukan sel darah merah dan hemoglobin dalam darah. Menurut Kristiana dan Herti (2008), rosela (Hibiscus sabdariffa L.) merupakan salah satu tanaman obat tradisional yang memiliki kandungan mineral, Fe dan vitamin $\mathrm{C}$ paling tinggi diantara tanaman obat tradisional yang memiliki kandungan mineral, seperti bayam (Amaranthus janjeticus), daun singkong (Manihot esculenta), daun katuk (Sauropus androgynus) dan lain sebagainya. Kandungan Fe dan vitamin C dalam daun lebih tinggi dibandingkan pada kelopak maupun bunga dari rosela tersebut.

Data Survei Kesehatan Rumah Tangga (SKRT) tahun 2012 menyatakan bahwa prevalensi anemia pada balita sebesar 40,5\%, ibu hamil sebesar 50,5\%, ibu nifas sebesar 45,1\%, remaja putri usia $10-18$ tahun sebesar $57,1 \%$ dan usia 19-45 tahun sebesar 39,5\%. Wanita mempunyai risiko terkena anemia paling tinggi terutama pada remaja putri. Meskipun anemia disebabkan oleh berbagai faktor, namun $\geq 50 \%$ kasus anemia yang terbanyak diseluruh dunia secara langsung disebabkan oleh kurangnya masukan zat gizi besi. Selain itu penyebab anemia gizi besi dipengaruhi oleh kebutuhan tubuh yang meningkat, akibat mengidap penyakit kronis dan kehilangan darah karena menstruasi.

Menurut Direktorat Jenderal Bina Kesehatan Masyarakat (2005) Kekurangan zat besi dapat menimbulkan gangguan atau hambatan pada pertumbuhan, baik sel tubuh maupun sel otak. Kekurangan kadar Hb dalam darah dapat menimbulkan gejala lesu, lemah, letih, lelah dan cepat lupa. Akibatnya dapat menurunkan prestasi belajar, olah raga dan produktifitas kerja. Selain itu anemia gizi besi akan menurunkan daya tahan tubuh dan mengakibatkan mudah terkena infeksi.

Indonesia merupakan negara yang kaya akan keanekaragaman hayati dengan jenis tumbuhan yang bervariasi, salah satunya tanaman matel. Tanaman Matel (Clerodendrum minahassae L.) "yang secara empiris merupakan salah satu tanaman yang banyak dimanfaatkan di Indonesia, khususnya di Maluku dan Sulawesi Utara (Minahasa). Secara empiris tanaman matel ini di Maluku dimanfaatkan sebagai obat penambah darah, dan secara spesifik merupakan salah satu dari solusi untuk mengatasi masalah anemia. Masyarakat maluku sejak dulu telah mengonsumsi tanaman matel ini sebagai sayuran maupun obat.

Tanaman bayam duri berasal dari genus Amaranthus. Salah satu spesies Amaranthus yang sering dikenal sebagai gulma pertanian adalah Bayam Duri (Amaranthus spinosus L.). Menurut (Lin, 2007) ekstrak Amaranthus spinosus mampu menstimulasi proliferasi sel limfosit B. Di dalam 100 gr Amaranthus spinosus terkandung Fe (besi) sebanyak 21 gr per 100 gr daun tanaman tersebut, sementara kandungan Mg sebanya 1166 gr/100 gr. Dari hasil penelitian menutur Lin (2007), kandungan mineral besi yang cukup tinggi pada tanaman bayam duri terindikasi mampu menjadi salah satu solusi untuk mengatasi anemia.

Juice merupakan minuman yang memiliki keseimbangan antara sukrosa dan asam (Sudarmadji, 1982 dalam Tri, 2010) dan juga menambahkan bahwa mix juice merupakan campuran dari dua buah atau lebih yang dihancurkan. Dalam hal ini, secara empiris Juice juga bisa berbahan dasar sayuran, dan merupakan salah satu cara yang paling mudah untuk mengonsumsi sayuran.Anggraini (2010) membagi jus menjadi dua, yaitu sari buah yang dihasilkan langsung dari proses pengempaan, penghancuran, dan penggilingan buah. Dan sari buah yang dihasilkan dari konsentrat dengan merekonstitusi konsentrat sari buah dengan air minum.Prinsip pembuatan juice adalah pengambilan atau pemisahan konsentrat dalam bentuk cair yang dilakukan dengan cara penghancuran, penyaringan dan pemasakan (pasteurisasi) tanpa dilakukan proses fermentasi. Proses pembuatan sari buah harus dapat mempertahankan sifat fisik, kimia, dan organoleptik dan karakter zat gizi sari buah aslinya (Anggraini, 2010).Jumlah air yang ditambahkan pada juice buah tergantung pada jenis buah yang digunakan dan kepekatan sari buah yang diinginkan. Umumnya pengenceran yang digunakan untuk juice buah adalah sebanyak tiga sampai dengan empat kali volume sari buah (Fachrudin, 2011). 


\section{Metode}

Tipe Subjek penelitian berupa mencit (Mus musculus) adalah mencit jantan, umur 8-10 minggu, berat badan 25-30 gram sebanyak 15 ekor, dikelompokkan menjadi 5 kelompok: Perlakuan 1 (Jus daun matel dan diinduksi kloramfenikol), Perlakuan 2 (Jus daun bayam duri dan diinduksi kloramfenikol), Perlakuan 3 (Jus kombinasi dan diinduksi kloramfenikol), Perlakuan 4 (diinduksi Kloramfenikol saja), dan Kontrol.

Diambil sampel segar, masing masing daun matel $50 \mathrm{~g}$ dan daun bayam duri 50 gram, dicuci dan dipotong kecil-kecil dan dimasukkan ke dalam belnder atau juicer kemudian tambahkan air sebanyak $50 \mathrm{~mL}$ dengan perbandingan 1:1 untuk memperoleh $100 \mathrm{~mL}$ jus Matel dan Bayam Duri. Selanjutnya dikonversi dari manusia (70 $\mathrm{kg}$ ) untuk mencit (20 gram) adalah 0.0026. sehingga didapatkan dosis untuk mencit adalah $0.26 \mathrm{~mL}$ dan $0.52 \mathrm{~mL}$ yang diberikan secara oral (Aldi, 2013).

Dosis kloramfenikol yang disuntikkan pada mencit adalah dosis terapi yaitu 4x250 mg/hari. Dosis akan dikonversikan ke mencit, dimana faktor konversi dari manusia (70 kg) untuk mencit (20 gram) adalah 0.0026 sehingga didapatkan dosis untuk mencit $=1000 \mathrm{mg}$ x $0.0026=2.6 \mathrm{mg} / 20$ gram BB (berat badan) $=130 \mathrm{mg} / \mathrm{kg} \mathrm{BB}$ (berat badan). Volume sediaan yang diberikan untuk mencit pada umumnya adalah $1 \%$ dari berat badan mencit.

Data hasil pengukuran kadar hemoglobin dan jumlah eritrosit diuji secara statistik untuk diuji normalitasnya dan homogenitasnya. Data normal dan homogen diuji dengan analisis varians (ANOVA) satu arah $(\alpha=0.05)$ untuk mengetahui ada tidaknya perbedaan antar kelompok perlakuan, dan dilakukan uji post-hoc untuk melihat beda nyata pada tiap perlakuan.

\section{Hasil Penelitian}

\section{a. Hasil Pengukuran Kadar Hemoglobin}

Hasil pengukuran kadar hemoglobin dilakukan menggunakan alat hemositometer digital. Hasil pengukuran kadar hemoglobin pada Perlakuan 1 (diinduksi kloramfenikol dan jus daun matel) kadar hemoglobin M1 sebesar $14.55 \mathrm{~g} / \mathrm{dL}$, M2 sebesar $14.52 \mathrm{~g} / \mathrm{dL}$, dan M3 sebesar $14.53 \mathrm{~g} / \mathrm{dL}$, dengan kadar hemoglobin rata-rata sebesar 14,5 $\mathrm{g} / \mathrm{dL}$. Untuk lebih jelasnya dapat dilihat pada Tabel 1 berikut ini :

Tabel 1. Hasil Pengukuran Kadar Hemoglobin Pada Kelompok Perlakuan 1

\begin{tabular}{cccc}
\hline Perlakuan & Subjek & $\begin{array}{c}\text { Kadar } \\
\text { Hemoglobin } \\
\text { (g/dL) }\end{array}$ & $\begin{array}{c}\text { Rata-rata } \\
\text { kadar } \\
\text { hemoglobin }\end{array}$ \\
\hline Jus Daun Matel & M1 & 14.55 & \\
+ Kloramfenikol & M2 & 14.52 & $14.53 \mathrm{~g} / \mathrm{dL}$ \\
& M3 & 14.53 & \\
\hline
\end{tabular}

Dari hasil pengukuran kadar hemoglobin terlihat jelas bahwa kelompok perlakuan 1 (diinduksi jus daun matel dan kloramfenikol) dengan kadar hemoglobin rata-rata $14.53 \mathrm{~g} / \mathrm{dL}$. Ini menunjukkan adanya peningkatan kadar hemoglobin yang lumayan signifikan dibanding kelompok pembandingnya yaitu kelompok perlakuan 2 (diinduksi jus daun bayam duri dan kloramfenikol) sebesar $10.53 \mathrm{~g} / \mathrm{dL}$ dan perlakuan 3 (diinduksi jus kombinasi dan kloramfenikol) sebesar $14.44 \mathrm{~g} / \mathrm{dL}$ dengan nilai $\mathrm{p} \geq 0.05$. Untuk melihat terdapat perubahan pada kadar hemoglobin perlakuan 1 maka dapat dilihat pada selisih perlakuan 1 dan perlakuan 4. Selisih kadar hemoglobin perlakuan 1 sebesar $(14.53 \mathrm{~g} / \mathrm{dL})$ dan perlakuan 4 sebesar $(11.24 \mathrm{~g} / \mathrm{dL})$ adalah $(3.29 \mathrm{~g} / \mathrm{dL})$. Terlihat bahwa terjadi peningkatan kadar hemoglobin yang cukup signifikan, dan ini mendukung hasil analisi varians bahwa nilai signifikansinya $<0.05$, sehingga hipotesis $\mathrm{H} 1$ diterima dan hipotesis $\mathrm{H} 0$ ditolak.

Menurut (Shrivasta dan Patel 2007) kandungan kimia dalam tanaman genus Clerodendrum yang terdiri atas golongan steroid, terpen, flavonoid, konsituen volatile, glikosida cianogenik, fenolik, karbohidrat, ribosomeinactivating protein, serta saponin (van Valkenburg dan Bynyapraphatsara 2002) diduga berkontribusi dalam efek hematologi jus yang diberikan kepada subjek kelompok perlakuan 1. Utami et al., (2017) melaporkan bahwa kadar abu total dalam simplisia sebesar 27,783\%.

Tingginya kadar abu menunjukkan tingginya kandungan mineral, dan dengan kandungan mineral yang tinggi ini, daun matel (Clerodendrum minahassae L.) dapat dijadikan sebagai sumber mineral, karena mineral merupakan mikronutrien yang berperan dalam pembentukan hemoglobin. Minarno dan Hariani (2008) menjelaskan bahwa zat besi merupakan komponen yang sangat penting dari hemoglobin, zat besi berfungsi dalam proses oksidasi reduksi dalam sel yang berhubungan dengan pembentukan energi. Dalam hal ini, zat besi merupakan kofaktor dari 
beberapa enzim yang terlibat dalam metabolisme energi. Mulyati (2003) menambahkan bahwa bentuk lain adalah non heme yaitu senyawa besi anorganik yang kompleks terdapat dalam bahan makanan nabati yang hanya dapat diabsorbsi 5\%.

Pada Perlakuan 2 (diinduksi kloramfenikol dan jus daun bayam duri) kadar hemoglobin M1 sebesar 10.54 $\mathrm{g} / \mathrm{dL}$, M2 sebesar $10.52 \mathrm{~g} / \mathrm{dL}$, dan M3 sebesar $10.55 \mathrm{~g} / \mathrm{dL}$, dengan kadar hemoglobin rata-rata sebesar 10,5 g/dL. Untuk lebih jelasnya dapat dilihat pada Tabel 2 berikut ini:

Tabel 2. Hasil Pengukuran Kadar Hemoglobin Pada Kelompok Perlakuan 2

\begin{tabular}{cccc}
\hline Perlakuan & Subjek & $\begin{array}{c}\text { Kadar } \\
\text { Hemoglobin } \\
(\mathbf{g} / \mathbf{d L})\end{array}$ & $\begin{array}{c}\text { Rata-rata } \\
\text { kadar } \\
\text { hemoglobin }\end{array}$ \\
\hline Jus Daun Bayam & M1 & 10.54 & \\
Duri + & M2 & 10.52 & $10.53 \mathrm{~g} / \mathrm{dL}$ \\
Kloramfenikol & M3 & 10.55 & \\
\hline
\end{tabular}

Pada kelompok perlakuan 2 (diinduksi jus daun bayam duri dan kloramfenikol) dengan kadar hemoglobin rata-rata sebesar $10.53 \mathrm{~g} / \mathrm{dL}$. Ini menunjukkan adanya penurunan kadar hemoglobin yang cukup signifikan dibanding kelompok perlakuan lainnya dengan kadar hemoglobin di atas $10 \mathrm{~g} / \mathrm{dL}$. Untuk melihat terdapat perubahan pada kadar hemoglobin perlakuan 2 maka dapat dilihat pada selisih perlakuan 2 dan perlakuan 4. Selisih kadar hemoglobin perlakuan 2 sebesar $(10.53 \mathrm{~g} / \mathrm{dL})$ dan perlakuan 4 sebesar $(11.24 \mathrm{~g} / \mathrm{dL})$ adalah $(-0.71 \mathrm{~g} / \mathrm{dL})$. Terlihat bahwa terjadi penurunan kadar hemoglobin, dan ini mendukung hasil analisi varians bahwa nilai signifikansinya $<0.05$, sehingga hipotesis H1 diterima dan hipotesis H0 ditolak. Diduga subjek mengalami anemia aplastik, kondisi dimana sumsum tulang subjek mengalami supresi, sehingga biosintesis hemoglobin terhambat, dan biosintesis eritrosit juga terhambat.

Pada Perlakuan 3 (diinduksi kloramfenikol dan kombinasi jus daun matel dan jus daun bayam duri) kadar hemoglobin M1 sebesar $14.46 \mathrm{~g} / \mathrm{dL}$, M2 sebesar $14.44 \mathrm{~g} / \mathrm{dL}$, dan M3 sebesar $14.43 \mathrm{~g} / \mathrm{dL}$, dengan kadar hemoglobin rata-rata sebesar 14,4 g/dL. Untuk lebih jelasnya dapat dilihat pada Tabel 3 berikut ini:

Tabel 3. Hasil Pengukuran Kadar Hemoglobin Pada Kelompok Perlakuan 3

\begin{tabular}{cccc}
\hline Perlakuan & Subjek & $\begin{array}{c}\text { Kadar } \\
\text { Hemoglobin } \\
\text { (g/dL) }\end{array}$ & $\begin{array}{c}\text { Rata-rata } \\
\text { kadar } \\
\text { hemoglobin }\end{array}$ \\
\hline Jus Kombinasi + & M1 & 14.46 & \\
Kloramfenikol & M2 & 14.44 & $14.44 \mathrm{~g} / \mathrm{dL}$ \\
& M3 & 14.43 & \\
\hline
\end{tabular}

Pada perlakuan 3 (diinduksi kombinasi jus daun matel dan jus daun bayam duri dan kloramfenikol) dengan kadar hemoglobin rata-rata 14,4 g/dL. Untuk melihat terdapat perubahan pada kadar hemoglobin perlakuan 2 maka dapat dilihat pada selisih perlakuan 3 dan perlakuan 4. Selisih kadar hemoglobin perlakuan 2 sebesar (14.44 g/dL) dan perlakuan 4 sebesar $(11.24 \mathrm{~g} / \mathrm{dL})$ adalah $(3.20 \mathrm{~g} / \mathrm{dL})$. Terlihat bahwa terjadi peningkatan kadar hemoglobin, dan ini mendukung hasil analisis varians bahwa nilai signifikansinya $<0.05$, sehingga hipotesis $\mathrm{H} 1$ diterima dan hipotesis H0 ditolak. Diduga kadar abu kedua bahan dan dosis yang tepat mampu meningkatkan kondisi hematologis kelompok perlakuan ini. Hal ini juga mempengaruhi efek kloramfenikol, karena kloramfenikol menekan aktivitas hematologis, sementara kedua bahan mempertahankan biosintesis hemoglobin dan eritrosit.

Pada Perlakuan 4 (diinduksi kloramfenikol saja) kadar hemoglobin M1 sebesar 11.26 g/dL, M2 sebesar 11.24 $\mathrm{g} / \mathrm{dL}$, dan M3 sebesar $11.22 \mathrm{~g} / \mathrm{dL}$, dengan kadar hemoglobin sebesar 11,2 g/dL. Untuk lebih jelasnya dapat dilihat pada Tabel 4.9 berikut:

Tabel 4. Hasil pengukuran kadar hemoglobin pada kelompok perlakuan 4

\begin{tabular}{cccc} 
Perlakuan & Subjek & $\begin{array}{c}\text { Kadar } \\
\text { Hemoglobin } \\
\text { (g/dL) }\end{array}$ & $\begin{array}{c}\text { Rata-rata } \\
\text { kadar } \\
\text { hemoglobin }\end{array}$ \\
\hline \multirow{2}{*}{ Kloramfenikol } & M1 & 11.26 & \\
& M2 & 11.24 & $11.24 \mathrm{~g} / \mathrm{dL}$ \\
& M3 & 11.22 & \\
\hline
\end{tabular}


Pada Perlakuan 5 (kontrol) kadar hemoglobin M1 sebesar 14.71 g/dL, M2 sebesar 14.73 g/dL, dan M3 sebesar $14.72 \mathrm{~g} / \mathrm{dL}$, dengan kadar hemoglobin rata-rata sebesar 14,7 g/dL. Untuk lebih jelasnya dapat dilihat pada Tabel 5 berikut:

Tabel 5. Hasil pengukuran kadar hemoglobin pada kelompok perlakuan 5

\begin{tabular}{cccc}
\hline Perlakuan & Subjek & $\begin{array}{c}\text { Kadar } \\
\text { Hemoglobin } \\
\text { (g/dL) }\end{array}$ & $\begin{array}{c}\text { Rata-rata } \\
\text { kadar } \\
\text { hemoglobin }\end{array}$ \\
\hline \multirow{3}{*}{ Kontrol } & M1 & 14.71 & \\
& M2 & 14.73 & $14.72 \mathrm{~g} / \mathrm{dL}$ \\
& M3 & 14.72 & \\
\hline
\end{tabular}

\section{b. Hasil Pengukuran Jumlah Eritrosit (RBC Count)}

Pengukuran jumlah eritrosit dilakukan menggunakan hemositometer digital dan dilakukan di RSKD Provinsi Maluku. Hasil menunjukkan adanya perbedaan yang cukup signifikan antar kelompok perlakuan. Untuk lebih jelasnya dapat disimak pada uraian data hasil pengukuran jumlah eritrosit berikut.

Pada Perlakuan 1 (diinduksi kloramfenikol dan jus daun matel) dengan jumlah eritrosit M1 sebesar $7.45 \mathrm{x}$ $10^{12} / \mathrm{L}$, M2 sebesar $7.43 \times 10^{12} / \mathrm{L}$, dan M3 sebesar $7.42 \times 10^{12} / \mathrm{L}$, serta rata-rata jumlah eritrosit sebesar $7.43 \times$ $10^{12} /$ L. untuk lebih jelasnya dapat dilihat pada Tabel 6 berikut:

\begin{tabular}{cccc} 
Tabel 6. Hasil Pengukuran Jumlah Eritrosit Pada Kelompok Perlakuan 1 \\
\cline { 2 - 4 } Perlakuan & Subjek & $\begin{array}{c}\text { Jumlah } \\
\text { Eritrosit } \\
\left(\mathbf{1 0}^{\mathbf{1 2}} / \mathbf{L}\right)\end{array}$ & $\begin{array}{c}\text { Rata-rata } \\
\text { Jumlah } \\
\text { Eritrosit }\end{array}$ \\
\hline Jus Daun Matel & M1 & 7.45 \\
+ Kloramfenikol & M2 & 7.43 & $7.43 \times 10^{12} / \mathrm{L}$ \\
& M3 & 7.42 & \\
\hline
\end{tabular}

Pada perlakuan 1 (diinduksi jus daun matel dan kloramfenikol) dengan jumlah eritrosit rata-rata $7.43 \times 10^{12} / \mathrm{L}$. Untuk melihat terdapat perubahan pada jumlah eritrosit perlakuan 1 maka dapat dilihat pada selisih perlakuan 1 dan perlakuan 4. Selisih jumlah eritrosit perlakuan 1 sebesar $\left(7.43 \times 10^{12} / \mathrm{L}\right)$ dan perlakuan 4 sebesar $(5.023 \times$ $\left.10^{12} / \mathrm{L}\right)$ adalah $\left(2.407 \times 10^{12} / \mathrm{L}\right)$. Terlihat bahwa terjadi peningkatan jumlah eritrosit per 1 triliun sel darah per liter, dan ini mendukung hasil analisis varians bahwa nilai signifikansinya $<0.05$, sehingga hipotesis $\mathrm{H} 1$ diterima dan hipotesis H0 ditolak.

Diduga mineral pendukung yang merupakan prekusor eritropoiesis seperti magnesium $(\mathrm{Mg})$ dan besi $(\mathrm{Fe})$ yang tinggi pada tanaman matel berkontribusi pada peningkatan yang terlihat. Kadar abu yang cukup tinggi yang dilaporkan oleh Utami et al (2017) melaporkan bahwa kadar abu total dalam simplisia sebesar 27,783\%. Tingginya kadar abu menunjukkan tingginya kandungan mineral, dan dengan kandungan mineral yang tinggi ini, daun matel (Clerodendrum minahassae L.) dapat dijadikan sebagai sumber mineral, karena mineral merupakan mikronutrien yang berperan dalam pembentukan eritrosit. Pada perlakuan 2 (diinduksi kloramfenikol dan jus daun bayam duri), dengan jumlah eritrosit M1 sebesar $3.61 \times 10^{12} / \mathrm{L}$, M2 sebesar $3.60 \times 10^{12} / \mathrm{L}$, dan M3 sebesar $3.62 \times 10^{12} / \mathrm{L}$, serta rata-rata jumlah eritrosit sebesar $3.61 \times 10^{12} / \mathrm{L}$. untuk lebih jelasnya dapat dilihat pada Tabel 7 berikut:

Tabel 7. Hasil pengukuran Jumlah Eritrosit pada kelompok perlakuan 2

\begin{tabular}{cccc}
\hline Perlakuan & Subjek & $\begin{array}{c}\text { Jumlah } \\
\text { Eritrosit } \\
\left(\mathbf{1 0}^{\mathbf{1 2}} / \mathbf{L}\right)\end{array}$ & $\begin{array}{c}\text { Rata-rata } \\
\text { Jumlah } \\
\text { Eritrosit }\end{array}$ \\
\hline Jus Daun Bayam & M1 & 3.61 & \\
Duri + & M2 & 3.60 & $3.61 \times 10^{12} / \mathrm{L}$ \\
Kloramfenikol & M3 & 3.62 & \\
\hline
\end{tabular}

Pada perlakuan 2 (diinduksi jus daun bayam duri dan kloramfenikol) dengan jumlah eritrosit rata-rata $3.61 \mathrm{x}$ $10^{12} / \mathrm{L}$. Untuk melihat terdapat perubahan pada jumlah etitrosit perlakuan 2 maka dapat dilihat pada selisih perlakuan 1 dan perlakuan 4. Selisih jumlah eritrosit perlakuan 2 sebesar $\left(3.61 \times 10^{12} / \mathrm{L}\right)$ dan perlakuan 4 sebesar $\left(5.023 \times 10^{12} / \mathrm{L}\right)$ adalah $\left(-1.413 \times 10^{12} / \mathrm{L}\right)$. Terlihat bahwa terjadi penurunan jumlah eritrosit yang cukup signifikan 
per 1 triliun sel darah per liter, dan ini mendukung hasil analisis varians bahwa nilai signifikansinya $<0.05$, sehingga hipotesis $\mathrm{H} 1$ diterima dan hipotesis $\mathrm{H} 0$ ditolak.

Efek kloramfenikol yaitu mensupresi sumsum tulang sehingga eritropoiesis dan transpor mineral penting ke dalam tulang terhambat, sehingga menyebabkan jumlah sel darah merah yang diproduksi berkurang dan jumlah eritrosit overall mengalami penurunan. A. spinosus yang mengandung mineral magnesium dan besi sampai 32 $\mathrm{mg}$ /gram brutto diduga belum mampu mencukupi kebutuhan tubuh akan mineral penting dalam eritropoiesis, sehingga jumlah eritrosit dan biositesis eritrosit tidak dapat berjalan dengan baik.

Pada perlakuan 3 (diinduksi kloramfenikol dan kombinasi jus daun matel dan jus daun bayam duri), dengan jumlah eritrosit M1 sebesar $6.96 \times 10^{12} / \mathrm{L}$, M2 sebesar $6.94 \times 10^{12} / \mathrm{L}$, dan M3 sebesar $6.92 \times 10^{12} / \mathrm{L}$, dengan jumlah eritrosit rata-rata sebesar $6.9 \times 10^{12} / \mathrm{L}$. untuk lebih jelasnya dapat dilihat pada Tabel 8 berikut:

Tabel 8. Hasil Pengukuran Jumlah Eritrosit Pada Kelompok Perlakuan 3

\begin{tabular}{cccc}
\hline Perlakuan & Subjek & $\begin{array}{c}\text { Jumlah } \\
\text { Eritrosit } \\
\left(\mathbf{1 0}^{\mathbf{1 2}} / \mathbf{L}\right)\end{array}$ & $\begin{array}{c}\text { Rata-rata } \\
\text { Jumlah } \\
\text { Eritrosit }\end{array}$ \\
\hline Jus Kombinasi + & M1 & 6.96 & \\
Kloramfenikol & M2 & 6.94 & $6.94 \times 10^{12} / \mathrm{L}$ \\
\hline
\end{tabular}

Pada perlakuan 3 (diinduksi jus daun matel dan kloramfenikol) dengan jumlah eritrosit rata-rata $6.94 \times 10^{12} / \mathrm{L}$. Untuk melihat terdapat perubahan pada jumlah eritrosit perlakuan 3 maka dapat dilihat pada selisih perlakuan 3 dan perlakuan 4. Selisih jumlah eritrosit perlakuan 3 sebesar $\left(6.94 \times 10^{12} / \mathrm{L}\right)$ dan perlakuan 4 sebesar $(5.023 \times$ $\left.10^{12} / \mathrm{L}\right)$ adalah $\left(1.917 \times 10^{12} / \mathrm{L}\right)$. Terlihat bahwa terjadi peningkatan jumlah eritrosit per 1 triliun sel darah per liter, dan ini mendukung hasil analisis varians bahwa nilai signifikansinya $<0.05$, sehingga hipotesis $\mathrm{H} 1$ diterima dan hipotesis H0 ditolak.

Diduga kadar abu total dalam simplisia C. minahassae sebesar 27,783\%, dengan tingginya kadar abu menunjukkan tingginya kandungan mineral, yang mana mineral merupakan mikronutrien yang berperan dalam eritropoiesis, serta $A$. spinosus yang mengandung mineral magnesium dan besi sampai $32 \mathrm{mg} / \mathrm{gram}$ brutto, sehingga kedua bahan mampu mencukupi kebutuhan tubuh akan mineral penting dalam eritropoiesis, sehingga jumlah eritrosit meningkat dan biositesis eritrosit dapat berjalan dengan baik.

Pada perlakuan 4 (diinduksi kloramfenikol saja), jumlah eritrosit M1 sebesar 5.023 x 10 $12 / \mathrm{L}$, M2 sebesar $5.025 \times 10^{12} / \mathrm{L}$, dan M3 sebesar $5.021 \times 10^{12} / \mathrm{L}$, dengan jumlah eritrosit rata-rata sebesar $5.02 \times 10^{12} / \mathrm{L}$. Untuk lebih jelasnya dapat dilihat pada Tabel 9 berikut:

Tabel 9. Hasil Pengukuran Jumlah Eritrosit Pada Kelompok Perlakuan 4

\begin{tabular}{cccc}
\hline Perlakuan & Subjek & $\begin{array}{c}\text { Jumlah } \\
\text { Eritrosit } \\
\left(\mathbf{1 0}^{\mathbf{1 2}} / \mathbf{L}\right)\end{array}$ & $\begin{array}{c}\text { Rata-rata } \\
\text { Jumlah Eritrosit }\end{array}$ \\
\hline \multirow{2}{*}{ Kloramfenikol } & M1 & 5.023 & \\
& M2 & 5.025 & $5.023 \times 10^{12} / \mathrm{L}$ \\
& M3 & 5.021 & \\
\hline
\end{tabular}

Pada Perlakuan 5 (kontrol) dengan jumlah eritrosit M1 sebesar $7.12 \times 10^{12} / \mathrm{L}, \mathrm{M} 2$ sebesar $7.15 \times 10^{12} / \mathrm{L}$, dan M3 sebesar $7.13 \times 10^{12} / \mathrm{L}$, dengan jumlah eritrosit rata-rata sebesar $7.1 \times 10^{12} / \mathrm{L}$. Untuk lebih jelasnya dapat dilihat pada Tabel 10 berikut:

Tabel 10. Hasil Pengukuran Jumlah Eritrosit Pada Kelompok Perlakuan 5

\begin{tabular}{cccc}
\hline Perlakuan & Subjek & $\begin{array}{c}\text { Jumlah } \\
\text { Eritrosit } \\
\left(\mathbf{( 1 0}^{\mathbf{1 2}} / \mathbf{L}\right)\end{array}$ & $\begin{array}{c}\text { Rata-rata } \\
\text { Jumlah Eritrosit }\end{array}$ \\
\hline \multirow{2}{*}{ Kontrol } & M1 & 7.12 & \\
& M2 & 7.15 & $7.13 \times 10^{12} / \mathrm{L}$ \\
& M3 & 7.13 & \\
\hline
\end{tabular}




\section{c. Hasil Analisis Data}

Data hasil pengukuran kadar hemoglobin dan jumlah eritrosit dianalisis menggunakan aplikasi SPSS, menggunakan One-Way Analysis of Variance (ANOVA satu jalur). secara umum, hasil analisis data menunjukkan adanya pengaruh yang sangat signifikan pemberian jus daun matel jus daun bayam duri, dan jus daun kombinasi. Data hasil analisis untuk tiap variabel dapat dilihat pada uraian dan tabel 11, Tabel 12, Tabel 13, Tabel 14, Tabel 15, Tabel 16, Tabel 17 dan Tabel 18 berikut:

1) Hasil Uji ANOVA untuk Kadar Hemoglobin

Terlihat pada tabel 11. ketiga perlakuan, jumlah pengulangan, rerata kadar hemoglobin tiap perlakuan.

\begin{tabular}{lccc}
\multicolumn{3}{c}{ Tabel 11. Tabel Deskriptif } \\
\hline \multicolumn{1}{c}{ Perlakuan } & N & Rerata & Standar Deviasi \\
\hline Jus Matel & 3 & 14.5333 & .01528 \\
Jus Bayam Duri & 3 & 10.5367 & .01528 \\
Jus Kombinasi & 3 & 14.4433 & .01528 \\
Total & 9 & 13.1711 & 1.97626 \\
\hline
\end{tabular}

Terlihat pada Tabel 12. bahwa nilai signifikan sebesar (.000), yang berarti bahwa nilai $\mathrm{p}<0.05$, sehingga hipotesis H1 diterima dan Hipotesis H0 ditolak. Dengan demikian dapat dikatakan bahwa jus daun matel, daun bayam duri, dan jus kombinasi mampu memberikan pengaruh terhadap kadar hemoglobin subjek.

Tabel 12. Hasil Uji Anova Untuk Kadar Hemoglobin

\begin{tabular}{ccccc}
\hline & Jumlah Kuadrat & df & Rata-rata Kuadrat & Sig \\
\hline Antar kelompok & 31.243 & 2 & 15.622 & .000 \\
Dalam kelompok & .001 & 6 & .000 & .000 \\
Total & 31.245 & 8 & & \\
\hline
\end{tabular}

Oleh karena nilai signifikansinya, maka dilakukan uji lanjut menggunakan uji Post-Hoc untuk mencari nilai beda antar perlakuan, yang dapat disimak pada tabel 13. berikut:

Tabel 13. Hasil Uji Post-Hoc Untuk Kadar Hemoglobin

\begin{tabular}{ccccc}
\hline \multirow{4}{*}{ LSD } & Perlakuan (I) & Perlakuan (J) & Rerata Perbedaan (I-J) & Sig \\
\cline { 2 - 5 } & Matel & Bayam Duri & 3.99667 & .000 \\
& & Kombinasi & .09000 & .000 \\
\cline { 2 - 5 } & Bayam Duri & Matel & -3.99667 & .000 \\
& & Kombinasi & -3.90667 & .000 \\
\cline { 2 - 5 } & Kombinasi & Matel & -.09000 & .000 \\
& Bayam Duri & 3.90667 & .000 \\
\hline
\end{tabular}

Dengan nilai $\mathrm{p}=0.05$

Terlihat pada tabel 13. bahwa nilai beda antar kelompok perlakuan sangat signifikan, sehingga dapat dinotasikan pada Tabel 14.berikut ini:

Tabel 14. Hasil Uji Lanjut Untuk Kadar Hemoglobin

\begin{tabular}{cccc}
\hline Jenis perlakuan & Rerata & Notasi \\
\hline Jus Bayam Duri & 10.5367 & $\mathrm{a}$ & \\
Jus Kombinasi & 14.4433 & $\mathrm{~b}$ & $\mathrm{c}$ \\
Jus Matel & 14.5333 & & \\
\hline
\end{tabular}

2) Hasil Uji ANOVA untuk Jumlah Eritrosit

Terlihat pada Tabel 15 ketiga perlakuan, jumlah pengulangan, rerata jumlah eritrosit tiap perlakuan. 
Tabel 15. Tabel Deskriptif Untuk Jumlah Eritrosit

\begin{tabular}{cccc}
\hline Perlakuan & N & Rerata & Standar Deviasi \\
\hline Jus Matel & 3 & 7.4333 & .01528 \\
Jus Bayam Duri & 3 & 3.6100 & .01000 \\
Jus Kombinasi & 3 & 6.9400 & .02000 \\
Total & 9 & 5.9944 & 1.80110 \\
\hline
\end{tabular}

Terlihat pada Tabel 16. bahwa nilai signifikan sebesar (.000), yang berarti bahwa nilai $\mathrm{p}<0.05$, sehingga hipotesis H1 diterima dan Hipotesis H0 ditolak. Dengan demikian dapat dikatakan bahwa jus daun matel, daun bayam duri, dan jus kombinasi mampu memberikan pengaruh terhadap jumlah eritrosit subjek.

Tabel 16. Hasil Uji Anova Untuk Jumlah Eritrosit

\begin{tabular}{ccccc}
\hline & Jumlah Kuadrat & df & Rata-rata Kuadrat & Sig \\
\hline Antar kelompok & 25.950 & 2 & 12.975 & .000 \\
Dalam kelompok & .001 & 6 & .000 & .000 \\
Total & 25.952 & 8 & & \\
\hline
\end{tabular}

Oleh karena nilai signifikansinya, maka dilakukan uji lanjut menggunakan uji Post-Hoc untuk mencari nilai beda antar perlakuan, yang dapat disimak pada Tabel 17. berikut:

Tabel 17. Hasil Uji Post-Hoc Untuk Jumlah Eritrosit

\begin{tabular}{ccccc}
\hline \multirow{4}{*}{ LSD } & Perlakuan $(\mathbf{I})$ & Perlakuan $(\mathbf{J})$ & Rerata Perbedaan (I-J) & Sig \\
\cline { 2 - 5 } & Matel & Bayam Duri & 3.82333 & .000 \\
& & Kombinasi & .49333 & .000 \\
\cline { 2 - 5 } & Bayam Duri & Matel & -3.82333 & .000 \\
& & Kombinasi & -3.33000 & .000 \\
\cline { 2 - 5 } & Kombinasi & Matel & -.49333 & .000 \\
& Bayam Duri & 3.33000 & .000 \\
\hline
\end{tabular}

Dengan nilai $\mathrm{p}=0.05$

Terlihat pada Tabel 17. bahwa nilai beda antar kelompok perlakuan sangat signifikan, sehingga dapat dinotasikan pada Tabel 18. berikut ini:

Tabel 18. Hasil Uji Lanjut Untuk Jumlah Eritrosit

\begin{tabular}{cccc}
\hline Jenis perlakuan & Rerata & Notasi \\
\hline Jus Bayam Duri & 3.6100 & $\mathrm{~A}$ & \\
Jus Kombinasi & 6.9400 & & $\mathrm{~b}$ \\
Jus Matel & 7.4333 & & $\mathrm{c}$ \\
\hline
\end{tabular}

\section{Kesimpulan}

Dari hasil dan pembahasan, dapat disimpulkan bahwa Jus Daun Matel (Clerodendrum minahassae L.) memberikan pengaruh yang cukup signifikan $(\mathrm{p} \leq 0.05)$ terhadap kadar hemoglobin rata-rata tertinggi sebesar 14,5 g/dL, diikuti oleh Jus Daun Kombinasi (Jus Daun Matel + Jus Daun Bayam Duri) dengan kadar hemoglobin ratarata sebesar 14,4 g/dL, dan yang terendah adalah pada perlakuan Jus Daun Bayam Duri (Amaranthus spinosus L.) dengan kadar hemoglobin rata-rata 10,5 g/dL. Jus Daun Matel (Clerodendrum minahassae L.) memberikan pengaruh yang cukup signifikan $(\mathrm{p} \leq 0.05)$ terhadap jumlah eritrosit dengan jumlah eritrosit rata-rata sebesar 7.43 x 10 12/L, diikuti oleh Jus Daun Kombinasi (Jus Daun Matel + Jus Daun Bayam Duri) dengan jumlah eritrosit ratarata sebesar $6.94 \times 10^{12} / \mathrm{L}$, dan yang terendah adalah pada perlakuan Jus Daun Bayam Duri (Amaranthus spinosus L.) dengan jumlah eritrosit rata-rata sebesar $3.61 \times 10^{12} / \mathrm{L}$. 


\section{Daftar Pustaka}

Aldi Yufri. 2013. Efek Jus Terung Pirus (cyphomandra betacea Send tn.) Terhadap Jumlah Sel Darah Merah (Eritrosit) dan Nilai Hematokrit Pada Mencit Putih Jantan. Padang

Aru W. Sudoyo. 2009. Buku Ajar Ilmu Penyakit Dalam. Jilid II. Edisi kelima. Jakarta. Interna Publishing

Ashok, B. S. K., Lakshman, K., Jayaveera, K. N., Arun, A.K., Manoj, B. and Sheshadri, S. D. 2010. Antioxidant and antipyretic properties of methanolic extract of Amaranthus spinosus leaves. Asian Pacific $J$ of Trop. Med. 3 (9): 702-706.

Bakta, IM. 2007. Hematologi Klinik Ringkas. Jakarta. Penerbit Buku Kedokteran EGC.

Barku, V. Y. A., Opoku-Boahen, Y., Owusu-Ansah, E. and Mensah, E. F. 2013. Antioxidant activity and the estimation of total phenolic and flavonoid contents of the root extract of Amaranthus spinosus. Asian J. Plant Sci. Res. 3(1): 69-74.

Bavarva, J. H. and Narasimhacharya, A. V. 2013. Systematic study to evaluat anti-diabetic potential of Amaranthus spinosus on type-1 and type-2 diabetes. Cell. Mol. Biol. 2(59):1818-1825.

Bi-Fong Lin et al, 2005. Amaranthus spinosus water extract directly stimulates proliferation of B Lymphocytes in vitro. Taiwan.

Dalimartha, Setiawan. 1999. Atlas Tumbuhan Obat Indonesia. Jilid 1. Trubus Agriwidya. Jakarta.

Di Rosa M, Giroud JP, Willoughby DA. 1971: Studies of the acute inflammatory response induced in rats in different sites by carrageenan and turpentine. J Pathol 104: 1529.

Dressler, S.; Schmidt, M. Zizka, G. 2014. Clerodendrum African Plants

Girija, K., Lakshman, K., Udaya, C., Sabhya, S.G., and Divya, T. 2011. Anti-diabetic and anti-cholesterolemic activity of methanol extracts of three species of Amaranthus. Asian Pac. J. Trop. Biomed. 1(2):133138.

Guyton, Arthur C. 1996. Fisiologi Manusia Dan Mekanisme Penyakit. Alih Bahasa: Petrus Andrianto. Jakarta: EGC.

Guyton, Arthur C dan John E Hall. 1997. Fisiologi Kedokteran. Jakarta: EGC.

Ham, Arthur W. 1969. Histology Seventh Edition. America: J.B. Lippincott Company. Philadelphia and Toronto.

Henry, F.C. 2001. Chloramphenicol, Tetracyclines, Macrolides, Clindamycin, \& Streptogramins. In: Katzung BG, editor. Basic \& Clinical Pharmacology, $8^{\text {th }}$ ed. New Your: McGraw-Hill;: 774-6.

Hilou, A., Nacoulmaa, O. G. and Guiguemdeb, T. R. 2006. In vivo antimalarial activities of extracts from Amaranthus spinosus L. and Boerhaavia erecta L. in mice. J. Ethnopharmacol. 103(2): 236-240.

Hoffbrand, AV. et al. 2005. Kapita Selekta Hematologi. Jakarta. Penerbit Buku Kedokteran EGC.

Hole, John W. 1998. Human Anatomy Physiology Sixth Edition. Dubuque, Lowa, Melbourne, Australia Oxford, England: Wm.c Brown Publishers.

Ibewuike JC, Ogundaini AO, Bohlin L, Ogungbamila FO 1997 Anti-inflammatory activity of selected Nigerian medicinal plants. Nig J Nat Pdts Med 1: 1014.

Ilango, K., Prakash, Y. G., Arun, K. K. and Kamakshi. S. 2010. Protective effect of aerial parts of Amaranthus spinosus Linn in Paracetamol induced hepatotoxicity in rats. Arch. Appl. Sci. Res. 2(1): 152-158.

Jhade, D., Ahirwar, D., Sharma, N. K., Hatwar, B., Gupta, S. and Jain, V. K. 2011. Antifertility activities of ethanolic and aqueous root extract of Amaranthus spinosus Linn. in rats. Pharmacol. online. 2: 959967.

Joshua, L. S., Pal, V. C., Kumar, K. L. S., Sahu, R. K. and Roy, A. 2010. Antitumor activity of the ethanol extract of Amaranthus spinosus leaves against EAC bearing swiss albino mice. Der. Pharmacia. Lettre. 2(2):10-15.

Lina, B. F., Chiang, B. L. and Lin, J. Y. 2005. Amaranthus spinosus water extract directly stimulates proliferation of B lymphocytes in vitro. Int. Immunopharmacol. 5: 711-722.

Kairupan C. F., Mantiri F. R., Rumende R. R. H. 2019. Phytochemical Screening and Antioxidant Activity of Ethanol Extract of Leilem (Clerodendrum minahassae Teijsm. \& Binn) as an Antihyperlipidemic and Antiatherosclerotic Agent. IOP Conference Series: Earth and Envirnmental Science. Manado.

Mansjoer, Arif. et al. 2007. Kapita Selekta Kedokteran. Jilid 2. Edisi Ketiga. Jakarta. Penerbit Buku Kedokteran EGC.

Odhav, 2006. Journal of Food Composition and Analysis 20. 2007: 430-435

Olajide OA, Awe SO, Makinde JM. 1997. Pharmacological studies on Newbouldia laevis stem bark. Fitoterapia 68: 439443. 
Olajide OA, Makinde JM, Awe SO. 1999. Effects of the aqueous extract of Bridelia ferruginea stem bark on carrageenan-induced oedema and granuloma tissue formation in rats and mice. J Ethnopharmacol 66: 113117.

Olajide OA, Makinde JM, Awe SO. 2000. Evaluation of the pharmacological properties of the nutmeg oil in rats and mice. Pharm Biol 38: 385390.

Olumayokun, A. O., Babatunde, R. O. and Temitope, O. E. 2004. Anti-inflammatory Properties of Amaranthus spinosus Leaf Extract. Pharmaceut. Biol. 42(7): 521-525.

Olufemi, B. E., Assiak, I. E., Ayoade, G. O. and Onigemo, M. A. 2003. Studies on the effects of Amaranthus spinosus leaf extract on the hematology of growing pigs. African J. Biomed. Res. 6: 149- 150.

Rista dan Yuziani, 2014. Efektivitas Madu Terhadap Peningkatan HB Pada Tikus Putih. Fakultas Farmasi Universitas Sumatera Utara. Medan.

Sangameswaran, B. and Jayakar, B. 2008. Anti-diabetic, anti-hyperlipidemic and spermatogenic effects of Amaranthus spinosus Linn. on streptozotocin-induced diabetic rats. J. Nat. Med. 62(1): 79-82.

Sherwood, Lauralee, 2001. Fisiologi Manusia Dari Sel Ke Sistem. Alih Bahasa: Brahm U. Jakarta: EGC.

Smith, J. B. dan Mangkoewidjojo, S. 1988. Pemeliharaan, Pembiakan, dan Penggunaan Hewan Percobaan di Daerah Tropis. Penerbit UI. Jakarta: 34-40.

Srivastava, A., Singh, K., Gul, T. and Ahirwar, V. 2011. Alterations in hematocellular components of albino rats due to methanolic extract of Amaranthus spinosus. Pharmacie. Globale. 3(6): 1-3.

Vane JR. 1971. Inhibition of prostaglandin synthesis as mechanism of action of aspirin-like drugs. Nature 231: 232235.

WHO. 2010. Worldwide Prevalence Of Anemia 1993 - 2005. WHO Global Database on Anemia

Widyastuti, 2013. Profil Darah Tikus Putih Wistar pada Kondisi Subkronis Pemberian Natrium Nitrit. Program Studi Biologi Fakultas Biologi Universitas Gadjah Mada. Yogyakarta.Wilson LM. Patofisiologi Konsep Klinik Proses Penyakit, 1995.

Wintobe, M.M. 1933. Microscopic Examination of Blood Am. J. Med. Sci. 185:58-59. 